\title{
Increased DNA synthesis of uninvolved psoriatic epidermis is maintained in vitro
}

\author{
K.KRAGBALLE, L.DESJARLAIS AND C.L.MARCELO \\ University of Michigan Medical School, Department of Dermatology, Ann Arbor, Michigan, U.S.A.
}

Accepted for publication 24 July 1984

SUMMARY

Clinically uninvolved psoriatic epidermis shows increased DNA synthesis in vivo. We have studied the DNA synthesis of cultured keratinocytes from uninvolved psoriatic skin. Trypsinized epidermal cells were plated on plastic dishes pre-coated with bovine collagen type I. In initial studies, normal human serum was found to be superior to fetal bovine in supporting the growth of human epidermal keratinocytes. Furthermore, keratinocyte cultures established in the presence of normal human serum produced large keratin proteins (68,000 daltons) indicating that the terminal steps in cell differentiation can occur in vitro. In subsequent experiments keratinocyte cultures were grown in medium supplemented with 10\% normal human serum. Confluent cultures of keratinocytes from uninvolved psoriatic epidermis had an increased DNA synthesis determined both as the incorporation of $\left[{ }^{3} \mathrm{H}\right]$ thymidine and as the autoradiographic labelling index. The DNA synthesis of both normal and psoriatic keratinocyte cultures increased in response to incubation in medium with $10 \%$ psoriatic serum. The ability of keratinocytes from uninvolved psoriatic epidermis to maintain an increased DNA synthesis suggests the presence of an inherent defect within the population of epidermal keratinocytes in psoriasis. Such a culture system can be used as an in vitro model for the study of psoriasis.

Both inflammation and abnormal epidermal growth are essential components of psoriatic skin lesions. Recently, much emphasis has been put on the inflammation occurring in psoriasis, but epidermal hyperproliferation remains the single best marker of psoriasis. An increased labelling index is seen in involved and, to a lesser degree, in uninvolved psoriatic epidermal keratinocytes (Hell \& Hodgson, 1966; Goodwin, Hamilton \& Fry, 1973; Grove, Auderton \& Smith, 1976; Marks, 1978; Rowe, Dixon \& Forsythe, 1978). The concept of increased epidermal DNA synthesis in uninvolved psoriatic epidermis is further supported by transplantation studies of uninvolved psoriatic skin to congenitally athymic mice (Krueger, Chambers \& Shelby, 198I). This property of uninvolved psoriatic epidermis makes it an attractive model to study the aberrant epidermal growth in psoriasis. The failure of culture systems to maintain the increased

Correspondence: Knud Kragballe, M.D., Department of Dermatology, University of Michigan Medical School, Box 056, Room 6558, Kresge I, Ann Arbor, MI 48109, U.S.A. 
proliferation of keratinocytes from uninvolved psoriatic skin (Liu \& Parsons, I983; West, Kenicer \& Faed, I983) has, however, limited the use of keratinocyte cultures as an in vitro model for the study of psoriasis. Another limitation has been that cultured keratinocytes only produce small keratin proteins $(40,000-58,000$ daltons) indicating that the final stages of keratin synthesis do not take place in vitro (Fuchs \& Green, 1978; Sun \& Green, 1978).

Using a modified culture system the aim of the present study was to determine the proliferation of keratinocytes from normal and uninvolved psoriatic epidermis.

\section{METHODS}

\section{Skin specimens}

Informed consent was obtained from adult patients with untreated psoriasis (skin involvement less than $20 \%$ ) and from an age-matched group of healthy volunteers without a history of skin disease. Keratome biopsies were taken from buttock skin at least $30 \mathrm{~cm}$ from psoriatic lesions.

\section{Keratinocyte cultures}

To establish keratinocyte cultures we used a modification of the procedure reported by Liu \& Karasek (1978). A keratome biopsy was incubated with $0.25 \%$ trypsin in PBS containing $5 \mathrm{mM}$ glucose $\left(\mathrm{pH} 7.0\right.$ ) for $30-40 \mathrm{~min}$ at $37^{\circ} \mathrm{C}$. After aspiration of trypsin, minimal essential medium (MEM) with $10 \%$ fetal bovine serum (FBS), $50 \mathrm{IU} / \mathrm{ml}$ penicillin and $50 \mu \mathrm{g} / \mathrm{ml}$ streptomycin was added. Then epidermis was separated from dermis, and the epidermal cells released into the medium by gently scraping and agitating both the epidermal and the dermal compartment of the biopsy. Epidermal cell suspensions $\left(0.7 \times 10^{6}\right.$ trypan blue-excluding cells per $\left.\mathrm{ml}\right)$ were plated on I $6 \mathrm{~mm}$ culture dishes pre-coated with a collagen type I gel (Vitrogen, Flow Laboratories). Cells were incubated at $37^{\circ} \mathrm{C}$ in $100 \%$ humidity in a $95 \%$ air $/ 5 \% \mathrm{CO}_{2}$ environment. After $24 \mathrm{~h}$ the plating medium was replaced with McCoy's 5A medium supplemented with 50 IU $/ \mathrm{ml}$ penicillin, $50 \mu \mathrm{g} / \mathrm{ml}$ streptomycin, $4 \times 10^{-4} \mathrm{M} \mathrm{L}$-serine and $10 \%$ of either FBS or normal human serum (NHS). NHS was obtained from healthy adult volunteers taking no medication. The medium was changed twice a week, and the cultures became confluent after I-3 weeks. The success rate of growing keratinocytes was $80-90 \%$.

\section{DNA synthesis}

DNA synthesis via the salvage pathway was determined by $\left[{ }^{3} \mathrm{H}\right]$ thymidine $\left(\left[{ }^{3} \mathrm{H}\right] \mathrm{TdR}\right)$ incorporation into terminally labelled cultures and by autoradiography as previously described by us (Marcelo et al., I978). For $\left[{ }^{3} \mathrm{H}\right] \mathrm{TdR}$ incorporation cultures were pulsed for $6 \mathrm{~h}$ with $\mathrm{I}$ $\left.\mu \mathrm{Ci} / \mathrm{ml} \mathrm{[}{ }^{3} \mathrm{H}\right] \mathrm{TdR}(60 \mathrm{Ci} / \mathrm{mmol})$. For autoradiography keratinocytes were grown on plastic coverslips (Lux, Flow Laboratories) and labelled for $16 \mathrm{~h}$ with ro $\mu \mathrm{Ci} / \mathrm{ml}\left[{ }^{3} \mathrm{H}\right] \mathrm{TdR}$. The labelling index was determined by counting the number of labelled nuclei of 250 cells in twenty-five fields.

The activity of the de novo pathway of DNA synthesis was evaluated by measuring the incorporation of $\mathrm{I} \mu \mathrm{Ci} / \mathrm{ml}\left[{ }^{14} \mathrm{C}\right]$ orotic acid $(46 \mathrm{Ci} / \mathrm{mmol}$ ) into cultures labelled for $6 \mathrm{~h}$. Since orotic acid is incorporated into both DNA and RNA, the DNA was separated from RNA before counting (Marcelo et al., 1978).

\section{Differentiation of keratinocyte cultures}

Extraction of epidermal protein fractions was performed as earlier described by us (Marcelo \& Tong, I983). After a $2 \mathrm{~h}$ pulse with $\mathrm{I} 0 \mu \mathrm{Ci} / \mathrm{ml}\left[{ }^{3} \mathrm{H}\right]$ leucine, five extraction buffers were used in 
series to separate the cell proteins into six fractions: high salt-soluble protein $\left(S_{2}\right)$, keratohyalin protein $\left(R_{2}\right)$, sodium dodecyl sulphate-soluble proteins $\left(S_{3}\right)$, non-disulphide cross-linked keratin $\left(S_{4}\right)$, disulphide cross-linked keratin $\left(S_{5}\right)$ and envelope protein $\left(R_{5}\right)$. Each protein fraction was then subjected to sodium dodecyl sulphate polyacrylamide gel electrophoresis and fluorography. For fluorography the gels were impregnated with $\mathrm{EN}^{3} \mathrm{HANCE}$, dried and exposed to X-Omat X-ray film at $-70^{\circ} \mathrm{C}$ for 2 weeks.

\section{Psoriatic serum}

Whole blood serum was obtained from untreated psoriatic patients with a skin involvement of $20 \%$ to $80 \%$. Ten per cent psoriatic serum in McCoy's $5 \mathrm{~A}$ medium was added to confluent epidermal keratinocyte cultures. After incubation for $72 \mathrm{~h}$ at $37^{\circ} \mathrm{C}$ the DNA synthesis was measured as described above.

\section{RESULTS}

In order to define the importance of the serum source on the growth of human epidermal keratinocytes in vitro, the cells were grown in McCoy's 5 A medium supplemented with $10 \%$ of FBS or NHS (Table I). Measured as the day of complete confluency of the keratinocytes, NHS was superior to FBS in supporting cell growth.

TABLE I. Growth of normal human
epidermal keratinocytes cultured in
$\begin{gathered}\text { McCoy's 5A medium with } 10 \% \text { of } \\ \text { fetal bovine serum (FBS) or normal } \\ \text { human serum (NHS) }\end{gathered}$
$\begin{aligned} & \text { Serum } \\ & \text { FBS }\end{aligned}$
$\begin{aligned} & 13(7-23) \\ & \text { NHS }\end{aligned}$

Results are expressed as medians and $95 \%$ confidence limits for experiment with 5 different keratinocyte donors. Experiments with NHS from 4 different donors gave similar results.

${ }^{\star} P<0.01$ (Wilcoxon's test for paired samples).

This capacity of NHS could be due to a mitogenic effect or to an enhanced growth secondary to increased plating efficiency. To evaluate these possibilities, DNA synthesis was measured in confluent keratinocyte cultures. Under these circumstances cells grown in NHS continued to synthesize more DNA than cells in FBS (Table 2). Heat treatment $\left(56^{\circ} \mathrm{C}\right.$ for $30 \mathrm{~min}$ ) of FBS and NHS had no effect on the DNA synthesis of keratinocytes (Table 2). Also, no difference was found between isologous and autologous NHS (Table 2). In subsequent experiments human epidermal keratinocyte cultures were established in medium supplemented with untreated, isologous NHS. Under these culture conditions, sodium dodecyl sulphate-polyacrylamide gel electrophoresis of the non-disulphide cross-linked keratin fraction $\left(S_{4}\right)$ of normal human 
TABLE 2. DNA synthesis of confluent cultures of normal human keratinocytes grown in medium with $10 \%$ fetal bovine serum (FBS) or normal human serum (NHS)

\begin{tabular}{|c|c|c|c|c|}
\hline Serum & $n$ & $\begin{array}{c}\text { Heat } \\
\left(56^{\circ} \mathrm{C} \text { for } 30 \mathrm{~min}\right)\end{array}$ & $\begin{array}{c}\text { DNA } \\
(\mu \mathrm{g} / \mathrm{I} 6 \mathrm{~mm} \text { well })\end{array}$ & $\begin{array}{c}{\left[{ }^{3} \mathrm{H}\right] \mathrm{TdR} \text { incorporation }} \\
\text { (c.p.m. } / \mu \mathrm{g} \text { DNA) }\end{array}$ \\
\hline FBS & 7 & $\circ$ & $7 \cdot 9(5 \cdot 2-10 \cdot 4)$ & $1085(720-1507)$ \\
\hline FBS & 5 & + & $8 \cdot I(4 \cdot 9-I I \cdot 8)$ & $995(690-1510)$ \\
\hline NHS (isologous) & 7 & 0 & $8 \cdot 5(5 \cdot 2-11 \cdot 7)$ & $1931(1223-2955)^{\star}$ \\
\hline NHS (isologous) & 5 & + & $8 \cdot 4(5 \cdot 5-12 \cdot 1)$ & I $830(\text { I I I I 5-286I) })^{\star}$ \\
\hline NHS (autologous) & 6 & o & $8.0(5 \cdot 3-10.8)$ & I $842(1222-2743)^{\star}$ \\
\hline
\end{tabular}

Results are expressed as medians and $95 \%$ confidence limits. Experiment with NHS from three different donors gave similar results.

$\star$ NHS vs. FBS: $P<0$ OI (Wilcoxon's test for unpaired samples).

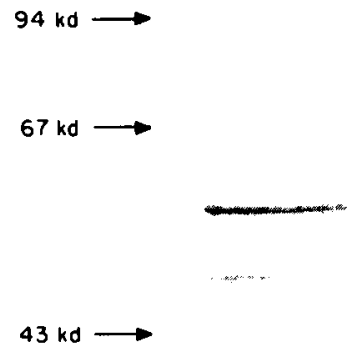

$30 \mathrm{kd} \longrightarrow$

$20 \mathrm{kd} \longrightarrow$

$14.4 \mathrm{kd} \longrightarrow$

FIGURE I. Separation by sodium dodecyl sulphate-polyacrylamide gel electrophoresis of polypeptides in the $\mathrm{S}_{4}$ fraction (non-disulphide cross-linked keratins) extracted from day 14 human keratinocyte cultures. Gels were stained with $0.25 \%$ Coomassie Brilliant Blue. Authentic standards are shown on the left. 
keratinocytes resolved bands with molecular weights ranging from 40,000 daltons to 68,000 daltons (Fig. I).

Table 3 compares the DNA content and the DNA synthesis of confluent epidermal keratinocyte cultures obtained from normal human skin or uninvolved psoriatic skin. Keratinocytes from uninvolved psoriatic skin showed an increase of DNA synthesis determined as the incorporation of $\left[{ }^{3} \mathrm{H}\right] \mathrm{TdR}$ into DNA. There was, however, an overlap of data when DNA synthesis of cultures from normal and uninvolved psoriatic epidermis was compared (Fig. 2). The $\left[{ }^{3} \mathrm{H}\right] \mathrm{TdR}$ used in both these assays is a precursor of the salvage pathway of DNA synthesis. The incorporation of $\left[{ }^{14} \mathrm{C}\right]$ orotic acid, a precursor of the de novo pathway, was equally low in cultures of keratinocytes from normal and uninvolved psoriatic skin (Table 3 ). The acid-soluble



FIGURE 2. Incorporation of $\left[{ }^{3} \mathrm{H}\right]$ thymidine into DNA of cultured keratinocytes from normal $(\bullet)$ and uninvolved psoriatic skin $(0)$. The horizontal bars indicate the median values. Psoriasis vs. normal: $P<0.0$ I (Wilcoxon's test for unpaired samples).

pool of $\left[{ }^{3} \mathrm{H}\right] \mathrm{TdR}$ was normal in keratinocyte cultures from psoriatics, indicating a normal cellular transport of $\left[{ }^{3} \mathrm{H}\right] \mathrm{TdR}$ (data not shown). To confirm that the $\left[{ }^{3} \mathrm{H}\right] \mathrm{TdR}$ data represented actual increase in proliferative rate rather than simply an altered uptake of $\left[{ }^{3} \mathrm{H}\right] \mathrm{TdR}$, cells were prepared for autoradiography (Table 3 ). Measured as the labelling index psoriatic keratinocytes also showed an increased DNA synthesis.

Replacement of the NHS with serum from patients with active psoriasis resulted in a stimulation of the DNA synthesis of keratinocyte cultures from both normal and uninvolved psoriatic skin (Table 4). The difference between normal and psoriatic keratinocytes was significant at the same statistical level as before adding psoriatic serum. 
TABLE 3. DNA synthesis of confluent cultures of human keratinocytes from normal and uninvolved psoriatic skin

\begin{tabular}{|c|c|c|c|c|}
\hline Keratinocytes & $\begin{array}{c}\text { DNA } \\
(\mu \mathrm{g} / 16 \mathrm{~mm} \text { well })\end{array}$ & $\begin{array}{l}\text { Labelling index } \\
\qquad(\%)\end{array}$ & $\begin{array}{c}{\left[{ }^{3} \mathrm{H}\right] \mathrm{TdR} \text { incorporation }} \\
\text { (c.p.m. } / \mu \mathrm{g} \text { DNA) }\end{array}$ & $\begin{array}{c}{\left[{ }^{14} \mathrm{C}\right] \text { orotic acid }} \\
\text { incorporation } \\
\text { (c.p.m./ug DNA) }\end{array}$ \\
\hline Normal & $8 \cdot 4(6 \cdot 2-12 \cdot 2)$ & II $(6-18)$ & $1890(1258-2810)$ & $3(1-5)$ \\
\hline Psoriasis & $8.6(6.4-12.5)$ & $16(10-23)^{\star}$ & $3555(2484-5$ I19) & $4(2-5)$ \\
\hline
\end{tabular}

Results are expressed as medians and $95 \%$ confidence limits for thirteen experiments.

$\star P<0.01$ (Wilcoxon's test for unpaired samples).

TABLE 4. Effect of psoriatic serum on the DNA synthesis of cultured keratinocytes from normal and uninvolved psoriatic skin

\begin{tabular}{|c|c|c|c|c|c|}
\hline Keratinocytes & Serum & $n$ & $\begin{array}{c}\text { DNA } \\
(\mu \mathrm{g} / \mathrm{I} 6 \mathrm{~mm} \text { well })\end{array}$ & $\begin{array}{l}\text { Labelling index } \\
(\%)\end{array}$ & $\begin{array}{c}{\left[{ }^{3} \mathrm{H}\right] \mathrm{TdR} \text { incorporation }} \\
\text { (c.p.m. } / \mu \mathrm{g} \text { DNA) }\end{array}$ \\
\hline Normal & Normal & I I & $8 \cdot 2(6 \cdot 6-10 \cdot 4)$ & $12(6-19)$ & $1854(1410-2675)$ \\
\hline Normal & Psoriasis & 8 & $8.6(6.0-10.4)$ & $17\left(\begin{array}{ll}1 & -24\end{array}\right) \star$ & $3417(2280-5222)^{\star}$ \\
\hline Psoriasis & Normal & 8 & $8.9(6 \cdot I-I I \cdot 2)$ & I6 $(9-23)^{\star \star}$ & $3900(2510-5510)^{\star \star}$ \\
\hline Psoriasis & Psoriasis & 5 & $7.9(5.5-11.0)$ & $22(14-30)^{\star \star \star}$ & $6574(4730-79 \mathrm{II})^{\star \star \star}$ \\
\hline
\end{tabular}

DNA synthesis was measured after incubation with $10 \%$ normal human serum or $10 \%$ psoriatic serum for $72 \mathrm{~h}$ at $37^{\circ} \mathrm{C}$.

* Psoriatic serum vs. normal serum: $P<0.01$.

$\star \star$ Psoriatic cells vs. normal cells: $P<0.01$.

$\star \star \star$ Psoriatic serum vs. normal serum: $P<0.01$.

\section{DISCUSSION}

In this study we have demonstrated that it is possible to maintain the increased DNA synthesis of uninvolved psoriatic epidermis in primary cultures of epidermal keratinocytes. The biopsies were obtained from patients with minimal clinical disease and taken at least $30 \mathrm{~cm}$ from lesional skin. It is, therefore, unlikely that subclinical disease or residual involvement from a previous clinical episode explains the increased DNA synthesis of epidermal keratinocytes from psoriatics. As in the in vivo situation, this increase of keratinocyte DNA synthesis was not accompanied by an increased DNA content of the cultures. Since enhanced DNA synthesis of keratinocyte cultures stimulated by leukotrienes also show no change of their DNA content (Kragballe, Desjarlais \& Voorhees, 1984), it is likely that the enhanced keratinocyte DNA synthesis is accompanied by an enhanced shedding of differentiated cells.

The abnormal proliferative activity of uninvolved psoriatic epidermis observed in vivo could be induced by signals from local dermal factors or from systemic factors born via the blood. However, the ability of epidermal keratinocytes to maintain the abnormal DNA synthesis in vitro suggests that this abnormality in psoriasis is inherent to the epidermal cells. Incubation with psoriatic serum resulted in a stimulation of the DNA synthesis of normal keratinocyte cultures. It can, however, be excluded that the increased DNA synthesis of cultured psoriatic 
keratinocytes is secondary to an in vivo exposure to psoriatic serum, because psoriatic keratinocytes were stimulated to the same degree as normal keratinocytes by psoriatic serum. The mitogenic properties of psoriatic serum will be further characterized in a future study.

Previously the in vitro behaviour of uninvolved psoriatic epidermis has been studied in both organ cultures and cell cultures. Using whole skin organ explants Harper, Rispler \& Urbanek (1978) reported a high labelling index of epidermal cells from uninvolved skin. In contrast to our results, two previous studies of epidermal cell cultures showed a normal proliferation of uninvolved psoriatic keratinocytes determined as the mitotic activity (Liu \& Parsons, I983) and as the surface area per cell colony (West et al., 1983). It is difficult to compare our results directly with those of the other studies because the culture techniques were different. In both of the cited studies epidermal keratinocytes were initially grown on $3 \mathrm{~T}_{3}$ feeder cell layers in the presence of FBS and hydrocortisone. Additional supplements were cholera toxin, epidermal growth factor (Liu \& Parsons, 1983) and insulin (West et al., 1983). Growth rates were then measured in secondary cultures without feeder layers and without the addition of most of the growth factors, although West et al. (1983) added cholera toxin. As demonstrated in the present study, the proliferation of human epidermal keratinocytes is suboptimal in medium with FBS. On the other hand, hydrocortisone, cholera toxin and epidermal growth factor enhance epidermal cell growth (Rheinwald, I980; Marcelo \& Tomich, 1983). In such a culture system the fine regulation of epidermal cell DNA synthesis may be disturbed leading to a change of the intrinsic behaviour of psoriatic keratinocytes. In support of this hypothesis is the lack of 67,000 dalton keratins in keratinocyte cultures established on $3 \mathrm{~T}_{3}$ feeder cell layers in the presence of FBS, hydrocortisone and cholera toxin (Fuchs \& Green, 1978; Sun \& Green, 1978). In contrast, our cell cultures synthesize these large keratins. Keratins of similar size, although not necessarily identical, are found in normal human stratum corneum (Inone, Fukuyama \& Epstein, r976; Sun \& Green, 1978). The presence of these keratins in our keratinocyte cultures, therefore, shows that the terminal stages of differentiation can occur in vitro. Since this group of keratins was not detected in previous studies of cultured keratinocytes (Sun \& Green, 1978), it has been assumed by some investigators that keratinocytes do not undergo terminal differentiation in vitro (Rheinwald, 1980; Friedberg, 1983). Our results do suggest that the production of keratins is determined by the culture conditions rather than by a basic difference in the in vivo and in vitro behaviour of keratinocytes.

The superiority of human serum to FBS in supporting the in vitro growth of human cells is not specific for keratinocytes, but has also been demonstrated for monocytes. Human monocytes can be maintained in vitro in the presence of human serum (10\%), whereas fetal or newborn calf, dog, horse and guinea-pig serum do not support monocyte cultures (Johnson, Mei \& Cohn, 1977). For monocytes, heat treatment $\left(56^{\circ} \mathrm{C}\right.$ for $\left.30 \mathrm{~min}\right)$ of the human serum resulted in a poor cell viability (Johnson et al., 1977), but from our study it appears that human keratinocytes are not dependent on the use of fresh serum.

In conclusion, we have demonstrated that it is possible to establish human epidermal keratinocyte cultures that synthesize the high molecular weight keratins typical of terminal cell differentiation. In such a culture system the epidermal keratinocytes from uninvolved psoriatic skin express increased DNA synthesis. The ability of psoriatic keratinocytes to maintain increased DNA synthesis in vitro strongly supports the presence of an inherent defect within the population of epidermal keratinocytes in psoriasis. Using this culture system as an in vitro model for the study of psoriasis, the differentiation of psoriatic keratinocytes is presently under investigation. 


\section{REFERENCES}

FRIEDBERG, I.M. (1983) Epidermal differentiation and differentiation and keratinization. In: Dermatology in General Medicine. Update. (Ed. by T.B.Fitzpatrick, A.Z.Eisen, K.Wolf, I.M.Friedberg and K.F.Austen), p. I59. McGraw Hill.

FuCHS, E. \& GREEN, H. (1978) The expression of keratin genes in epidermis and cultured cells. Cell, 15, 887.

Goodwin, P., HAMILToN, S. \& FRY, L. (1973) A comparison between DNA synthesis and mitosis in uninvolved and involved psoriatic epidermis and normal epidermis. British fournal of Dermatology, 89, 6 I 3.

Grove, G.L., AUDERTON, R.L. \& SMITH, J.G. (1976) Cytomorphometric studies of epidermal proliferation in psoriatic and normal skin. fournal of Investigative Dermatology, 66, 236.

HARPER, R.A., RISPLER, J. \& URBANEK, R.W. (1978) DNA synthesis among uninvolved and involved psoriatic epidermal cells in vitro. fournal of Investigative Dermatology, 70, 254 .

Hell, E. \& HodGson, C. (1966) The uptake of ${ }^{3} \mathrm{H}$-thymidine by epidermal cells in normal and psoriatic subjects. British fournal of Dermatology, 78, 262 :

INONE, N., FUKUYAMA, K. \& EPSTEIN, W.L. (1976) Immunochemical studies of proteins in epidermal cornified cells of human and newborn rat. Biochimica et Biophysica Acta, 439, 95.

Johnson, W.D. JR, MEI, B. \& CoHN, Z.A. (I977) The separation, long-term cultivation, and maturation of the human monocyte. Fournal of Experimental Medicine, 146, 1613.

Kragballe, K., Desjarlais, L. \& VoorheEs, J.J. (1984) Leukotriene $\mathrm{B}_{4}, \mathrm{C}_{4}$ and $\mathrm{D}_{4}$ stimulate the DNA synthesis of human epidermal keratinocyte cultures. Fournal of Investigative Dermatology, 82, 398.

KRUEGER, G., CHAMBERS, D. \& SHELBY, J. (1981) Involved and uninvolved skin from psoriatic subjects: Are they equally diseased? Assessment by skin transplanted to congenitally athymic (nude) mice. Fournal of Clinical Investigation, 68, 1548 .

LIU, S.-C. \& KARASEK, M. (1978) Isolation and growth of adult human epidermal keratinocytes. Fournal of Investigative Dermatology, 71, 157.

LIU, S.-C. \& PARSONS, C.S. (1983). Serial cultivation of epidermal keratinocytes from psoriatic plaques. fournal of Investigative Dermatology, $81,54$.

Marcelo, C.L., Kim, Y.G., Kaine, J.L. \& VoorheEs, J.J. (1978) Stratification, specialization, and proliferation of primary keratinocyte cultures. Journal of Cell Biology, 79, 356.

MARCELO, C.L. \& TONG, P.S.L. (1983) Epidermal keratinocyte growth: Changes in protein composition and synthesis of keratins in differentiating cultures. Fournal of Investigative Dermatology, 80, 37.

MARKS, R. (1978) Epidermal activity in the involved and uninvolved skin of patients with psoriasis. British fournal of Dermatology, 98, 399.

Rheinwald, J.G. (1980) Serial cultivation of normal human epidermal keratinocytes. Methods in Cell Biology, 21A, 299.

Rowe, L., Dixon, W.J. \& Forsythe, A. (1978) Mitoses in normal and psoriatic epidermis. British fournal of Dermatology, 98, 293.

SUn, T.-T. \& GREEN, H. (1978) Keratin filaments of cultured human epidermal cells. fournal of Biological Chemistry,

253, 2053 .
WEST, M.R., KENICER, K.J.A. \& FAED, M.J.W. (1983) In vitro growth rates of epidermal cells derived from the skin of psoriatic patients and non-psoriatic controls. British fournal of Dermatology, 108, 533. 
This document is a scanned copy of a printed document. No warranty is given about the accuracy of the copy. Users should refer to the original published version of the material. 